\title{
ROS1 Gene Mutation
}

National Cancer Institute

\section{Source}

National Cancer Institute. ROS1 Gene Mutation. NCI Thesaurus. Code C130952.

A change in the nucleotide sequence of the ROS1 gene. 